\title{
THE EFFECT OF DIFFERENT LEVELS OF DISCARDED DATE PALM ON THE GROWTH PERFORMANCE OF NILE TILAPIA FINGERLINGS (Oreochromis niloticus)
}

\author{
Malik M. Khalafalla ${ }^{2}$; Said A. Mahmoud ${ }^{1}$; Fawzy I. Magouz ${ }^{1}$; \\ and Ahmed, K. G ${ }^{1}$ \\ ${ }^{1}$ Department of Animal Production, Faculty of Agriculture, \\ KafrelsheikhUniversity, Egypt. ${ }^{2}$ Department of Aquaculture, \\ Faculty of Aquatic and Fisheries Sciences, \\ KafrelsheikhUniversity, Egypt.
}

\begin{abstract}
This work was carried out in fish Research laboratory, Department of Animal Production, Faculty of Agriculture, Kafr El-Shiekh University. The feeding experiments dated from September until December 2014, feeding experiment was conducted for 12 weeks to study the effect of using different levels $(0,25,50,75$ and $100 \%)$ of discarded date with wheat bran (DDPW) on growth performance, efficiency of feed utilization, and preliminary economical evaluation of Nile tilapia (0. niloticus) fingerlings. A total of 225 fish with average initial body $14.4 \mathrm{~g}$, were randomly stoked into 15 aquaria (15 in each). Fish in all treatments were daily fed the experimental diets at a level of $3 \%$ of the fish biomass until the end of the experiment. The feed amount was given at two times daily, six days a week for 12 weeks. The results showed that all growth performance parameters and feed utilization values of the experimental fish were decreased significantly $(P<0.05)$ by increasing the level of DDPW in the diets. Diet contained 100\% DDPW was significantly lower $(P>0.05)$ for all the growth performance parameters as compared with the other treatments. The group fed the control diet (100\% yellow corn) recorded the highest values while those fed the diet containing 100\% DDPW recorded the lowest values while, those fed diets containing 25, 50 and $75 \%$ DDPW had significantly lower growth performance as compared with the control diet (100\% yellow corn). Economically, the change (\%) in feed cost $/ \mathrm{Kg}$ gain increased significantly $(P<0.05)$ with increasing the level of DDPW in the diets.
\end{abstract}

Keywords: Discarded date palm, growth performance, feed utilization, economic efficiency and Nile Tilapia.

\section{INTRODUCTION}

Nile tilapia (O.niloticus) was one of the first fish cultured species. Illustrations from Egyptian tombs suggested that Nile tilapia were cultured more than 3,000 years ago. Nile tilapia is still the most widely cultured species of tilapia in Africa. World food fish aquaculture production expanded at an average annual rate of 6.2 percent in the period 2000-2012 (9.5 percent in 1990-2000) from 32.4 million to 66.6 
million tones. In the same period, growth was relatively faster in Africa (11.7 percent) (FAO, 2014).

All over the world in tropical and sub-tropical areas, the numbers of date palm trees are increased dramatically because of its suitability to be grown under arid conditions. Wasted date and date byproducts are promising non-traditional carbohydrate sources in animal nutrition.

Utilization of date by-products in animal feeds was first carried out by Ali et al., (1956) for dairy cows. AlHiti and Rous (1978) and AlYousef et al., (1986) investigated the utilization of date by products for broiler, Nagib et al., (1994) for layer hen and Aldosari et al., (1995) for sheep.

Date waste contains carbohydrates and minerals and is a significant source of energy; thus, it may be possible to use date waste as an energy source for ruminants. Date fruit can provide $2.67 \mathrm{Mcal} / \mathrm{kg}$ of digestible energy. In comparison, barley provides $3.06 \mathrm{Mcal} / \mathrm{kg}$ of digestible energy (Alhomidy et al., 2011). Date-pits are generally used as complementary feed materials for animals and poultry or as a conventional soil fertilizer (Vandepopuliere et al., 1995). These are also used for extracting oil for cosmetic and pharmaceutical purposes (Devshony et al., 1992).

The world production of date fruit increases 2.9 times over 40 years, whereas the world production reached To 7.68 million tons in 2010. Date fruit can provide many essential nutrients and potential health benefits to the host. Date fruit goes through four ripening stages named by kimri, khalal, rutab and tamer. Tang et al., (2013).

Date palm has a wide range of existent in Arab region and Egypt especially in Siwa Oasis. Discarded date palm is candidate to play a rule in yellow corn substitution, as a non conventional and cheap energy.

The aim of the present study is to determine the possibility of using different levels $(0,25,50,75$, and $100 \%)$ of discarded date palm (DDPW) with kernel as a dietary energy source instead of yellow corn in the diets of Nile tilapia and its effect on growth performance, efficiency of feed utilization and economic efficiency.

\section{MATERIALS AND METHODS}

The present study was carried out in fish research laboratory, Department of Animal Production, Faculty of Agriculture, Kafr ElShiekh University.

The feeding experiments dated from September until December 2014 , feeding experiment was conducted for 12 weeks to study the effect of using different levels of discarded date with wheat 
bran (DDPW) on growth performance, efficiency of feed utilization ,and preliminary economical evaluation of Nile tilapia ( 0 . niloticus) fingerlings.

\section{Experimental design of rearing fish:}

A total number of 15 glass aquaria $(80 \times 35 \times 40 \mathrm{~cm})$ containing equal amount of water ( 80 liters) in each were used for performing the experiments. Each aquarium was supplied with compressed air through air pump for oxygen requirements. Fresh tap water was used for replacing about one third of the total water volume in each aquarium daily after the removal of fecal wastes. Water temperature was controlled thermostatically by automatic heaters and measured two times daily using a thermometer, water temperature ranged between $21.03-21.23^{\circ} \mathrm{C}$.

\section{Experimental fish:}

A set of 225 of Nile tilapia fingerlings (O. niloticus) were used in the experiment with14.4 g average initial body weight /fish, all fishes were taken from a private tilapia hatchery located in El-zawya area in Kafr El-Sheikh Governorate. The fishes were transported in plastic pages filled with water and oxygen to the wet lab in Kafr El- Sheikh Faculty of Agriculture.

All fishes were kept two weeks in a fiber glass tank before their distribution in the experimental aquaria for the adaptation on the new environment. The fishes were randomly divided into equal groups in the experimental aquaria ( 15 fish /aquarium).

The fish were fed a control diet containing $31.65 \%$ protein at a rate of $3 \%$ of total biomass during the acclimatization period. Three fish groups were used to test every experimental treatment.

\section{Experimental diets:}

Before the starting of the experiment, the fish were adapted to a basal commercial diet [control diet (T1)] containing 31, 65 crude protein and consisted of fish meal, soybean meal, yellow corn and wheat bran for two weeks. Five experimental commercial diets were formulated to contain discarded date palm (DDPW) at five levels 0,25 , 50,75 and $100 \%$ from the yellow corn (Table 1). Each diet was fed to three randomly assigned aquaria.

The basal diets were formulated to contain representing five diet variants, used for feeding of fish. A basic diet (control) was formulated of grounded yellow corn (33\%), soy bean meal (42\%), fish meal $(10 \%)$, wheat bran (5\%), Rice bran (5\%), vegetable oils (3\%), Di calcium phosphate $(1 \%)$, mineral mixture and vitamin mixture $(1 \%)$. 
The other four experimental diets were formulated by replacing yellow corn by discarded date palm at levels of $25,50,75$ and $100 \%$.

The ingredients of the experimental diets were ground in a hammer mill and mixed well together for homogenity. Thereafter, the water $(25 \%)$ was added to the mixture which was allowed to pass through a mincing machine to produce $2.5 \mathrm{~mm}$ pellets in diameter. The wet pellets were dried in an oven at $60^{\circ} \mathrm{C}$ for 24 hours . The diet collected, tagged and stored.

Table (1): Composition of the experimental diets (\%)

\begin{tabular}{|l|c|c|c|c|c|}
\hline Ingredients,\% & 1Control & D2 & D3 & D4 & D5 \\
\hline fish meal & 10 & 10 & 10 & 10 & 10 \\
\hline soybean meal & 42 & 42 & 42 & 42 & 42 \\
\hline yellow corn & 33 & 24.75 & 16.5 & 8.25 & - \\
\hline Discarded date & - & 8.25 & 16.5 & 24.75 & 33 \\
\hline Rice bran & 5 & 5 & 5 & 5 & 5 \\
\hline Wheat bran & 5 & 5 & 5 & 5 & 5 \\
\hline vegetable oils & 3 & 3 & 3 & 3 & 3 \\
\hline Di calcium phosphate & 1 & 1 & 1 & 1 & 1 \\
\hline Vit \& min. mixture* & 0.1 & 0.1 & 0.1 & 0.1 & 0.1 \\
\hline Total & 100 & 100 & 100 & 100 & 100 \\
\hline
\end{tabular}

* Each 1 kg. Contains vitamin A, 4.8 I.U.; vit D2 , $0.8 \mathrm{~m}$ I.U; vit E, 4.0 g; vit. K, 0.8 g; vit B1, 0.49, vit. B2, 1.6 g; vit. B6, 0.6 g; vit. B12, 4 mg; Pantothenic acid 49; Nicotinc acid 8 g; Folic acid, 400 mg; Biotin, $20 \mathrm{mg}$; Choline chloride, $200 \mathrm{mg}$; Copper, $4.0 \mathrm{~g}$; lodine, $0.4 \mathrm{~g}$; Iron, $12 \mathrm{mg}$; Manganese, $22 \mathrm{~g}$; Zinc $22 \mathrm{~g}$ and Selenium $0.04 \mathrm{~g}$.

Fish in all treatments were fed daily on the experimental diets at a level of $3 \%$ of the fish biomass until the fourth week and then fed a level of $2 \%$ from the fifth week until the end of the experiment. The feed was offered twice daily at 9.0 a.m and 3.0 p.m.

The fish groups were weighed weekly and the amount of the feed was adjusted according to the actual body weight changes.

\section{Analytical methods:}

Measurements of water parameters:

Water samples were taken weekly from each aquarium to determine water quality parameters such as the values of $\mathrm{PH}$, dissolved oxygen concentration and temperature. Light was adjusted by a timer to provide $14 \mathrm{~h}$ light and $10 \mathrm{~h}$ darkness. One third of water volume was changed daily and the whole water volume was totally changed every week.

Water temperature was measured by using a thermometer (daily), water $\mathrm{pH}$ value was determined by using digital $\mathrm{pH}$ meter (Orient Research Model 201), and dissolved oxygen concentration by using an oxygen meter (model 9070). 


\section{Experimental procedure:}

The experiment continued for 12 weeks. During the experimental period, fish were fed the diets at a rate of $3 \%$ of the live body weight daily and the feed was offered twice daily at 9.0 a.m and 3.0 p.m. The fish groups were weighed weekly and the amount of the feed was adjusted according to the actual body weight changes.

\section{Chemical analysis:}

Proximate analysis of discarded date palm, experimental diets and whole fish bodies were carried out for determining moisture, ash, protein and fat according to the methods described by A.O.A.C. (1990). Nitrogen free extract (NFE) was calculated by difference.

\section{Growth and feed utilization parameters:}

\section{Growth and efficiency of feed and protein utilization parameters:}

Average weight gain (AWG), average daily gain (ADG), specific growth rate (SGR \% d), feed conversion ratio (FCR), protein efficiency ratio (PER) and protein productive value (PPV\%) and survival rate (SR) were calculated according to the following equations: Average weight gain AWG (g/fish) $=W t-W 0$.

Average daily weight gain $A D G$ (g/fish/day) $=W t-W 0 /$ t.

Specific growth rate \% day SGR (\%/day) $=100 \times(\ln W t-\ln W 0) / t$

${ }^{* *}$ Where $\mathrm{Wt}$ is weight of fish at time $\mathrm{t}, \mathrm{W} 0$ is weight of fish at time 0 , and $t$ is the experimental period in days.

Feed conversion ratio, $\mathrm{FCR}=$ dry feed fed/wet weight gain.

Protein efficiency ratio, $\mathrm{PER}=$ wet weight gain/ Protein fed.

Protein productive value, PPV $(\%)=100 \times$ (protein gain / protein fed).

Survival rate, $S R=100$ (Total No. of fish at the end of the experimental/Total No. of fish at the start of the experiment].

\section{Organs indices:}

Five fish from each aquarium were killed at the end of the experiment, and then abdominal cavity was opened to remove liver which was weighed individually. Hepatic somatic index (HSI) was calculated as follow:

HSI =Liver weight $\times 100 /$ Gutted fish weight (Jangaard et al., 1967).

\section{Economic evaluation:}

Economic evaluation of the experimental diets has been calculated by evaluation the feed cost in Egyptian pound (L.E) needed to produce $1 \mathrm{~kg}$ of live weight gain of each experimental fish group.

Feed cost (L.E) $=($ feed cost $/ \mathrm{kg}) X$ (food consumption)

Cost $($ LE/gain "kg") $=($ feed cost $/ \mathrm{kg})$ X FCR . 


\section{Statistical analysis:}

The data were statistically analyzed using computer program SPSS (1997) for one way analysis of variance Duncan's multiple range test (1955) was used to test differences among means.

\section{Chemical composition:}

\section{RESULTS AND DISCUSSION}

Chemical composition of the different ingredients used in the experimental diets is shown in Table (2). Which include soybean meal; herring fish meal, rice bran, wheat bran and yellow corn. The average chemical composition of yellow corn Table (2) is in agreement with Abd El-Maksoud et at., (1999); Khalil(2001) ; Osman et al.,(2002,) and Khalafalla (2008), they reported that the chemical composition of yellow corn (on DM basis) was ranged from 89.62- 92.92\% for DM; 96.95-98.93\% for OM; 7.54- $11.25 \%$ for CP; $2.99-7.48 \%$ for EE; $1.63-$ $3.89 \%$ for CF; 77.98 - $85.94 \%$ for NFE and 1.07 - 3.05\% for Ash.

\section{Discarded date palm (DDPW):}

Results in Table (2) showed that average chemical composition of discarded date palm in this study is in agreement with Selmi et al,.(2011). They reported that the chemical composition of discarded date palm were from 83.8 to $90.40 \% \mathrm{DM}, 95.96$ to $98.14 \%$ for OM , 5.07 to $8.69 \%$ for CP , 3.10 to $6.00 \%$ for EE,3.90 to $10.00 \%$ for CF and 3.07 to $9.5 \%$ for ash. Dates contain about $70-80 \%$ simple sugars (glucose and fructose).

A comparison between the proximate chemical analysis of yellow corn and discarded date palm (DDPW) is shown in Table (2). The results revealed that yellow corn contained higher dry matter, organic matter, crude protein, ether extract, nitrogen free extract and gross energy than DDPW. However DDPW contained higher crude fiber and ash than yellow corn. These findings are in partial agreement with the finding of Srour et al., (2002), whilst the obtained results are different somewhat with the finding of Nour et al.,(2004) in crude protein, crude fiber, nitrogen free extract and gross energy. These differences may be attributed to the use of DDPW with kernel in the present study. 
Table (2): Chemical analysis of ingredients used in the experimental diets (On DM basis \%)

\begin{tabular}{|c|c|c|c|c|c|c|c|c|}
\hline Ingredients & DM & OM & CP & EE & CF & Ash & NFE & $\begin{array}{c}\mathrm{GE}^{\star} \\
\text { Kcal/ } \\
100 g\end{array}$ \\
\hline $\begin{array}{c}\text { Soybean } \\
\text { meal }\end{array}$ & $\begin{array}{c}91.8 \\
0\end{array}$ & $\begin{array}{c}92.1 \\
5\end{array}$ & $\begin{array}{c}44.5 \\
0\end{array}$ & 6.23 & 5.90 & 7.85 & $\begin{array}{c}35.5 \\
2\end{array}$ & $\begin{array}{c}460.2 \\
0\end{array}$ \\
\hline Fish meal & 92.2 & 89.5 & $\begin{array}{c}71.9 \\
7\end{array}$ & $\begin{array}{c}14.6 \\
5\end{array}$ & 0.90 & $\begin{array}{c}10.5 \\
0\end{array}$ & 1.98 & $\begin{array}{c}553.4 \\
3\end{array}$ \\
\hline Rice bran & $\begin{array}{c}94.3 \\
3\end{array}$ & $\begin{array}{c}89.0 \\
7\end{array}$ & $\begin{array}{c}11.3 \\
6\end{array}$ & 8.48 & $\begin{array}{c}19.5 \\
2\end{array}$ & $\begin{array}{c}10.9 \\
3\end{array}$ & $\begin{array}{c}49.7 \\
1\end{array}$ & $\begin{array}{c}354.0 \\
9\end{array}$ \\
\hline Wheat bran & $\begin{array}{c}90.4 \\
5\end{array}$ & 95.2 & $\begin{array}{c}11.5 \\
2\end{array}$ & 6.98 & 9.00 & 4.98 & $\begin{array}{c}67.5 \\
2\end{array}$ & $\begin{array}{c}415.9 \\
9\end{array}$ \\
\hline Yellow corn & $\begin{array}{c}89.1 \\
0\end{array}$ & 97.5 & 8.85 & 7.45 & 1.90 & 2.50 & 79.3 & $\begin{array}{c}455.0 \\
5\end{array}$ \\
\hline $\begin{array}{c}\text { Discarded } \\
\text { date palm }\end{array}$ & $\begin{array}{c}80.7 \\
6\end{array}$ & $\begin{array}{c}89.7 \\
6\end{array}$ & 8.31 & 3.16 & 6.74 & $\begin{array}{c}10.2 \\
4\end{array}$ & $\begin{array}{c}71.5 \\
5\end{array}$ & $\begin{array}{c}378.7 \\
6\end{array}$ \\
\hline
\end{tabular}

*Gross energy was calculated according to NRC (1993) by using factors of 5.65, 9.45 and 4.22 Kcal per 100 gram of protein, lipid and carbohydrate, respectively.

\section{Chemical composition of the experimental diets:}

Chemical composition and calculated gross energy of different experimental diets are presented in Table (3). The experimental diets were isonitrogenous, and contained nearly similar DM, CP, EE, CF, Ash, FE and GE content and P/E ratio. The DM content ranged from 88.93 to 91.58 ; OM from 89.81 to 92.2 ; CP 30.05 from to 31.65 ; EE from 15.43 to 16.00 ; CF from 3.38 to 5.14 ; ash from 7.80 to 10.19 and NFE from 36.87 to $42.13 \%$. The corresponding value of GE ranged from 4.86 to 5.03 ; DE from 3.64 to $3.77 \mathrm{kcal} / \mathrm{g}$ and $\mathrm{P} / \mathrm{E}$ from 81.54 to $87.23 \mathrm{mg} / \mathrm{kcal}$. The data revealed that both of CF and ash content increased by increasing the level of discarded date palm in the diet while the NFE content decreased.

Table (3): Chemical composition of the experimental diets

\begin{tabular}{|c|c|c|c|c|c|}
\hline Item & $\begin{array}{c}\text { D1 } \\
\text { Control }\end{array}$ & D2 & D3 & D4 & D5 \\
\hline DM & 91.19 & 91.05 & 91.58 & 91.56 & 88.93 \\
\hline OM & 92.2 & 91.73 & 91.68 & 90.63 & 89.81 \\
\hline CP & 31.65 & 31.05 & 30.09 & 30.05 & 31.8 \\
\hline EE & 15.88 & 15.74 & 15.43 & 15.81 & 16.00 \\
\hline CF & 3.38 & 3.48 & 4.04 & 4.75 & 5.14 \\
\hline ASH & 7.80 & 8.27 & 8.32 & 9.37 & 10.19 \\
\hline NFE & 41.29 & 41.46 & 42.12 & 40.02 & 36.87 \\
\hline Calculated energy value: & 5.03 & 4.99 & 4.93 & 4.88 & 4.86 \\
\hline GE $^{1}$ (kcal/g) & 3.77 & 3.74 & 3.69 & 3.66 & 3.64 \\
\hline $\mathbf{D E}^{2}$ (kcal/g) & 83.95 & 83.2 & 81.54 & 82.10 & 87.23 \\
\hline $\mathbf{P}^{3}$ (mg/kcal) &
\end{tabular}


${ }^{1} \mathrm{GE}$ (gross energy) was calculated according to NRC (1993) by factors of 5.65, 9.45 and 4.22 kcal per gram of protein, Lipid and carbohydrate, respectively.

${ }^{2} \mathrm{DE}$ (digestible energy) was calculated by applying the coefficient of 0.75 to convert gross energy to digestible energy.

${ }^{3} \mathrm{P} / \mathrm{E}($ protein energy ratio $)=$ crude protein $\times 10000 /$ digestible energy.

\section{Water quality parameters:}

Water quality parameters of the experimental aquaria were insignificantly affected by different treatments during the experimental period (12 weeks). Average water analytical data are summarized in Table (4). In genera1, average water temperature of the different treatments was ranged between 21.03 and $21.23^{\circ} \mathrm{C}$. Averages of $\mathrm{pH}$ values were ranged from 7.73 to 7.94 . The concentration of dissolved oxygen (mg/L) was ranged between 4.49 and $5.48 \mathrm{mg} / \mathrm{L}$ which are suitable for fish growth. Averages of $\mathrm{NH} 3$ values were ranged from 0.13 to 0 . 17. Data indicated that the values obtained lie in the acceptable ranges required for normal growth of tilapia. All values of the abovementioned parameters were suitable for the normal growth and reproduction of tilapia and warm water fish (Tahoun, 2002).

Table (4): Average of some physical and chemical parameters of water during the experimental period

\begin{tabular}{|c|c|c|c|c|c|}
\hline $\begin{array}{l}\text { Diets } \\
\text { no. }\end{array}$ & $\begin{array}{l}\text { Discarded } \\
\text { date } \%\end{array}$ & $\begin{array}{c}\text { Water } \\
\text { temper- } \\
\text { ature }\end{array}$ & Water PH & $\begin{array}{c}\mathrm{DO} \\
(\mathrm{mg} / \mathrm{L})\end{array}$ & $\begin{array}{c}\text { Total } \\
\text { ammonia } \\
(\mathrm{mg} / \mathrm{L})\end{array}$ \\
\hline Control & - & $\begin{array}{c}21.06^{b c} \\
\pm 0.03\end{array}$ & $\begin{array}{l}7.94^{a} \\
\pm 0.04\end{array}$ & $\begin{array}{l}4.49^{c} \\
\pm 0.18\end{array}$ & $\begin{array}{l}0.14^{b} \\
\pm 0.03\end{array}$ \\
\hline T2 & 25 & $\begin{array}{c}21.16^{\mathrm{ab}} \\
\pm 0.03\end{array}$ & $\begin{array}{l}7.87^{\mathrm{ab}} \\
\pm 0.02\end{array}$ & $\begin{array}{l}5.05^{b} \\
\pm 0.19\end{array}$ & $\begin{array}{l}0.13^{b} \\
\pm 0.05\end{array}$ \\
\hline T3 & 50 & $\begin{array}{l}21.03^{C} \\
\pm 0.03\end{array}$ & $\begin{array}{l}7.86^{a b} \\
\pm 0.01\end{array}$ & $\begin{array}{l}5.48^{a} \\
\pm 0.01\end{array}$ & $\begin{array}{l}0.14^{\mathrm{b}} \\
\pm 0.03\end{array}$ \\
\hline T4 & 75 & $\begin{array}{c}21.23^{a} \\
\pm 0.03\end{array}$ & $\begin{array}{l}7.81^{\mathrm{bc}} \\
\pm 0.02\end{array}$ & $\begin{array}{l}5.43^{a b} \\
\pm 0.04\end{array}$ & $\begin{array}{l}0.17^{a} \\
\pm 0.05\end{array}$ \\
\hline T5 & 100 & $\begin{array}{c}21.16^{\text {ab }} \\
\pm 0.03\end{array}$ & $\begin{array}{l}7.73^{\mathrm{C}} \\
\pm 0.04\end{array}$ & $\begin{array}{l}5.3^{a b} \\
\pm 0.05\end{array}$ & $\begin{array}{l}0.17^{a} \\
\pm 0.03\end{array}$ \\
\hline
\end{tabular}

\section{Feed intake and nutrient utilization:}

Nutrients utilization in terms of feed intake $(\mathrm{FI})$, feed conversion ratio (FCR), protein efficiency ratio (PER) for tilapia fed diets containing different levels of DDPW are illustrated in (Table 5). Fish received diets contained 0 and $25 \%$ DDPW recorded higher feed intake values than that contained 50 and $75 \%$, there were no significant differences $(P>0.05)$ in feed intake among fish fed diets 3 and 4 contained 50 and 75\% DDPW. Diet contained 100\% DDPW was 
significantly lower $(P>0.05)$ in feed intake as compared with the other treatments.

Nour et al., (2004) indicated that fish group fed the diets contained 0, 25 and 50\% IDDD (Inedible dried dropping dates) recorded higher feed intake values than that contained 100\% IDDD. The data also, pointed out that the FCR were significantly the worst $(P<0.05)$ for fish fed the diet contained 100\% DDPW as compared with those fed other diets. On the other hand, the differences between the diet containing 50 and $75 \%$ DDPW were not significant; while fish fed the diet containing 0 and $25 \%$ DDPW had better value.

No significant differences $(P>0.05)$ were noticed among fish fed diets contained 50 and $75 \%$ DDPW in PER, the control diet and diet contained 25\% DDPW replacement levels was significantly higher $(\mathrm{P}<0.05)$ compared with the other treatments. Fish fed the diet containing $100 \%$ DDPW had the lowest value.

Srour et al., (2002) reported that, there were insignificant differences $(P>0.05)$ between fish received the control diet and $25 \%$ DDD (dried dropping dates) in protein efficiency ratio (PER) and feed conversion ratio (FCR). The same trend was also reported by Nour et al., (2004) who indicated that no significant differences $(P>0.05)$ were noticed among fish fed diets contained 0,25 and $50 \%$ and among those contained 75 and $100 \%$ IDDD in protein efficiency ratio (PER) and feed conversion ratio.

Hussein et al., (1998) concluded that adding date pits to the finisher diets improved body weight gain and feed conversion of broiler chicks. The addition of date pits, dates and date fruit to the starter diets showed growth performance comparable to the corn-soybean meal diet. The results showed that date pits, whole dates and date fruit can be included at $10 \%$ in broiler diets to support and enhance growth performance.

However, with replacement of $100 \%$ Wheat flour by untreated date pits, significant reduction $(\mathrm{P}<0.05)$ in feed utilization parameters was noticed, but treating the same replacement level with $70 \%$ sulfuric acid, utilization of the carbohydrate source was improved.

Table (5): Average of feed intake, feed conversion ratio, protein efficiency ratio (\%) of Nile tilapia fed different experimental diets

\begin{tabular}{|c|c|c|c|c|}
\hline Diets no. & discarded date \% & $\begin{array}{c}\text { Feed intake } \\
\text { g/fish }\end{array}$ & FCR & PER \\
\hline Control & 0 & $36.59 \pm 0.13^{\mathrm{a}}$ & $2.22 \pm 0.35^{\mathrm{d}}$ & $1.43 \pm 0.28^{\mathrm{a}}$ \\
\hline T2 & 25 & $34.03 \pm 0.93^{\mathrm{b}}$ & $2.74 \pm 0.17^{\mathrm{c}}$ & $1.17 \pm 0.06^{\mathrm{b}}$ \\
\hline T3 & 50 & $26.74 \pm 0.89^{\mathrm{C}}$ & $4.96 \pm 0.10^{\mathrm{b}}$ & $0.66 \pm 0.01^{\mathrm{c}}$ \\
\hline T4 & 75 & $26.86 \pm 0.66^{\mathrm{c}}$ & $5.21 \pm 0.01^{\mathrm{b}}$ & $0.61 \pm 0.02^{\mathrm{c}}$ \\
\hline T5 & 100 & $23.57 \pm 0.39^{\mathrm{a}}$ & $7.45 \pm 0.17^{\mathrm{a}}$ & $0.42 \pm 0.01^{\mathrm{a}}$ \\
\hline
\end{tabular}




\section{Growth performance and survival rate:}

Data concerning growth responses of Nile tilapia fingerlings presented as initial and final weight, average weight gain, average daily gain, specific growth rate and survival rate are shown in Table (6). Fish fed diets containing $25 \%$ DDPW had significantly lower growth performance as compared with the control diet (100\% yellow corn). Omar and Nour (1993) found that incorporation of $25 \%$ immature dates fruit dropping (IDF) in the diet of Nile tilapia ( $O$. niloticus) resulted in a significantly lower growth performance compared to the control diet (100\% yellow corn). No significant differences $(P>0.05)$ were noticed among fish fed diets contained 50 and $75 \%$ DDPW for all growth parameters.

The fish fed control diet recorded the highest values for all growth parameters. The diet contained 25\% DDPW recorded higher growth performance than the diet contained 50, 75 and 100\% DDPW. The lower growth performance for the fish fed the diet containing 100 $\%$ DDPW may be firstly due to the date seeds content (kernels) and secondly to the high contend of the simple surges found in the dates which may be not utilized efficiently by tilapia than dextrin or starch (shiau and lin., 1993).

Nour et al., (2004) indicated that no significant differences ( $P>0.05$ ) between fish received diets of 50 and $75 \%$ IDDD (Inedible dried dropping dates) in specific growth rate (SGR \%). Similar results have been obtained by srour et al., (2002) with catfish (Clarias $g$ ariepinus). No significant differences $(P>0.05)$ were noticed among all group fish fed different diets in survival rate (SR).

In Nile tilapia, final weights, average weight gain, average daily gain, specific growth rate significantly $(P<0.05)$ decreased with increasing DDPW levels in the diets. These results were in agreement with the finding of yousef et al., (1996) who found that blue tilapia O.aureus fed diet contained $25 \%$ of date had higher growth performance than the control diet contained $100 \%$ yellow corn.

The same trend was also reported by Omar and Nour (1993) who found that incorporation of $25 \%$ immature dates fruit dropping (IDF) in the diets of Nile tilapia (O. niloticus) resulted in a significantly lower growth performance compared to the control diet (100\% yellow corn). Al-Jasser (1996) found that with increasing the inclusion rate of date by-products up to $30 \%$, instead of corn flower in Oreochromis niloticus diets, fish weight gain was increased significantly $(\mathrm{P}<0.05)$.

They suggested a certain dietary ratio between complex and simple sugars of 3:1 for best performance of tilapia fish. This may explain the reduction of weight gain obtained in the present study when untreated date pits (high fiber content) was the only source of carbohydrate in fish feeds. 
Osman et al.,(1996) found that replacement of $100 \%$ of wheat flour in the diets of Oreoehromis nilotieus fish by untreated date pits (diet 5 ) reduced significantly $(P<0.05)$ weight gain and SGR. However, the differences between weight gain of groups (control, 2, 3 and 4) Wheat flour in diets 2 and 4 was replaced by $50 \%$ ( $15 \%$ of the total diet) and $100 \%$ (30\% of the total diet) untreated date pits, respectively.

Also, treated date pits inclusion at $50 \%$ and $100 \%$ of the wheat flour in diets 3 and 5 , respectively were not significant $(P>0.05)$. Fish group received diet 3 , where $50 \%$ of the wheat flour was replaced by treated date pits showed the highest growth values. It seems that sulfuric acid treatment had reduced the crude fiber content of the date pits which consequence increases the utilization of the diets.

Table (6): Growth performance parameters of Nile tilapia fed different the experimental diets:

\begin{tabular}{|c|c|c|c|c|c|c|}
\hline $\begin{array}{c}\text { Diets } \\
\text { no. }\end{array}$ & $\begin{array}{c}\text { Initial } \\
\text { BW } \\
\text { g/fish }\end{array}$ & $\begin{array}{c}\text { Final } \\
\text { BW } \\
\text { g/fish }\end{array}$ & $\begin{array}{c}\text { AWG } \\
\text { g/fish }\end{array}$ & $\begin{array}{c}\text { ADG } \\
\text { g/fish/da } \\
\text { y }\end{array}$ & $\begin{array}{c}\text { SGR } \\
\text { (\%/day) }\end{array}$ & SR (\%) \\
\hline Control & 14.4 & $30.90^{\mathrm{a}}$ & $16.50^{\mathrm{a}}$ & $0.17^{\mathrm{a}}$ & $0.91^{\mathrm{a}}$ & $99.22^{\mathrm{b}}$ \\
& \pm 0.00 & \pm 0.29 & \pm 0.29 & \pm 0.01 & \pm 0.01 & \pm 0.78 \\
\hline \multirow{2}{*}{ T2 } & 14.4 & $26.86^{\mathrm{b}}$ & $12.46^{\mathrm{b}}$ & $0.13^{\mathrm{b}}$ & $0.74^{\mathrm{b}}$ & $99.22^{\mathrm{b}}$ \\
& \pm 0.00 & \pm 0.72 & \pm 0.72 & \pm 0.01 & \pm 0.03 & \pm 0.78 \\
\hline T3 & 14.4 & $19.78^{\mathrm{c}}$ & $5.38^{\mathrm{c}}$ & $0.07^{\mathrm{c}}$ & $0.38^{\mathrm{c}}$ & $99.22^{\mathrm{b}}$ \\
& \pm 0.00 & \pm 0.12 & \pm 0.12 & \pm 0.003 & \pm 0.01 & \pm 0.78 \\
\hline T4 & 14.4 & $19.55^{\mathrm{c}}$ & $5.15^{\mathrm{c}}$ & $0.06^{\mathrm{c}}$ & $0.37^{\mathrm{c}}$ & $99.22^{\mathrm{b}}$ \\
& \pm 0.00 & \pm 0.05 & \pm 0.05 & \pm 0.003 & \pm 0.003 & \pm 0.78 \\
\hline T5 & 14.4 & $17.54^{\mathrm{d}}$ & $3.17^{\mathrm{d}}$ & $0.04^{\mathrm{d}}$ & $0.24^{\mathrm{d}}$ & $100^{\mathrm{a}}$ \\
& \pm 0.00 & \pm 0.10 & \pm 0.12 & \pm 0.00 & \pm 0.01 & \pm 0.00 \\
\hline
\end{tabular}

\section{Internal organs indices:}

The effect of different levels of discarded date palm on fish organs indices are shown in Table 7. It was indicated that there was no significant difference $(\mathrm{P}>0.05)$ in hepato somatic index $(\mathrm{HSI})$ between the diets contained 50 and $75 \%$ DDPW. Fish received diets contained $25 \%$ DDPW had a significantly higher HSI value as compared with the control diet ( $100 \%$ yellow corn).

Liver index was the lowest in the diet contained $100 \%$ DDPW. The highest ( $\mathrm{HSI}$ ) was found in diet contained 25\%DDPW. Generally, from the above results in the present study, the discarded date palm caused positive effects on the internal organs. 
Table (7): Organs indices of Nile tilapia fingerlings fed different levels of discarded date palm

\begin{tabular}{|c|c|c|}
\hline Treatment & Discarded date $\%$ & HSI \\
\hline Control & 0 & $3.27 \pm 0.20^{\mathrm{b}}$ \\
\hline T2 & 25 & $3.47 \pm 0.05^{\mathrm{a}}$ \\
\hline T3 & 50 & $2.44 \pm 0.19^{\mathrm{c}}$ \\
\hline T4 & 75 & $2.03 \pm 0.10^{\mathrm{c}}$ \\
\hline T5 & 100 & $1.57 \pm 0.05^{\mathrm{d}}$ \\
\hline
\end{tabular}

\section{Body composition and energy content of Nile tilapia:}

Body composition including dry mater (DM), crude protein (CP), ether extract (EE) ash and energy content of Nile tilapia at the beginning and at the end of the experiment are shown in table (8).

The results indicated that there were no significant differences ( $P>0.05)$ between fish received diets contained 25\% DDPW and control diet in carcass dry matter, also among fish fed diets contained 50, 75 and $100 \%$ DDPW. Whilst, no significant differences $(P>0.05)$ were noticed among all experimental diets in carcass CP. Similar results have been obtained by Nour et al., (2004). Furthermore, There were no significant differences $(P>0.05)$ either between fish received the control diet (100\% yellow corn) and fish fed diet contained $25 \%$ DDPW in carcass ether extract or among fish fed diets contained 50, 75 and $100 \%$ DDPW.

Table (8): Body composition (\%) of Nile tilapia as affected by the experimental diets:

\begin{tabular}{|c|c|c|c|c|c|c|}
\hline Diets no & $\begin{array}{c}\text { Discarded } \\
\text { date }\end{array}$ & DM & CP & EE & ASH & $\begin{array}{c}\text { GE (Kcal/ } \\
100 \mathrm{~g})\end{array}$ \\
\hline $\begin{array}{c}\text { Initial } \\
\text { fish }\end{array}$ & - & $\begin{array}{l}92.3^{\mathrm{d}} \\
\pm 0.17 \\
\end{array}$ & $\begin{array}{l}62.72^{\text {ab }} \\
\pm 0.003 \\
\end{array}$ & $\begin{array}{c}10.17^{\mathrm{d}} \\
\pm 0.04 \\
\end{array}$ & $\begin{array}{c}24.78^{\mathrm{a}} \\
\pm 0.01 \\
\end{array}$ & $\begin{array}{c}450.49^{c} \\
\pm 0.36 \\
\end{array}$ \\
\hline control & 0 & $\begin{array}{c}95.51^{\mathrm{a}} \\
\pm 0.17\end{array}$ & $\begin{array}{c}65.48^{a} \\
\pm 0.43\end{array}$ & $\begin{array}{c}24.81^{\text {ab }} \\
\pm 0.59\end{array}$ & $\begin{array}{c}15.83^{\mathrm{C}} \\
\pm 1.05\end{array}$ & $\begin{array}{c}604.43^{\mathrm{a}} \\
\pm 5.23^{2}\end{array}$ \\
\hline T2 & 25 & $\begin{array}{c}95.50^{\text {ab }} \\
\pm 0.59\end{array}$ & $\begin{array}{c}60.95^{b} \\
\pm 0.82\end{array}$ & $\begin{array}{c}26.07^{\mathrm{a}} \\
\pm 1.57\end{array}$ & $\begin{array}{c}18.23^{\mathrm{bc}} \\
\pm 1.07\end{array}$ & $\begin{array}{c}590.73^{\text {ab }} \\
\pm 15.68\end{array}$ \\
\hline T3 & 50 & $\begin{array}{c}94.36^{\mathrm{C}} \\
\pm 0.48\end{array}$ & $\begin{array}{c}63.50^{\text {ab }} \\
\pm 1.37\end{array}$ & $\begin{array}{c}20.92^{\mathrm{C}} \\
\pm 1.48\end{array}$ & $\begin{array}{c}19.01^{\mathrm{bc}} \\
\pm 0.42\end{array}$ & $\begin{array}{c}556.54^{b} \\
\pm 16.57\end{array}$ \\
\hline T4 & 75 & $\begin{array}{c}94.65^{\mathrm{bc}} \\
\pm 0.35\end{array}$ & $\begin{array}{c}65.16^{\mathrm{a}} \\
\pm 1.27\end{array}$ & $\begin{array}{c}22.03^{\mathrm{bc}} \\
\pm 1.01\end{array}$ & $\begin{array}{l}21.12^{\mathrm{ab}} \\
\pm 0.40\end{array}$ & $\begin{array}{c}576.36^{\text {ab }} \\
\pm 10.99\end{array}$ \\
\hline T5 & 100 & $\begin{array}{c}94.47^{b} \\
\pm 0.18\end{array}$ & $\begin{array}{c}64.73^{a} \\
\pm 0.48\end{array}$ & $\begin{array}{c}20.35^{\mathrm{c}} \\
\pm 1.40\end{array}$ & $\begin{array}{c}24.70^{a} \\
\pm 2.26\end{array}$ & $\begin{array}{c}556.78^{b} \\
\pm 15.91\end{array}$ \\
\hline
\end{tabular}

Yousif et al., (1996) reported that increasing body protein content and decreasing fat was observed in $O$. aureus fed diets supplemented with the dates. There were no significant differences 
( $P>0.05$ ) between fish received diets of $50,75 \%$ and $100 \%$ IDDD in ash and gross energy. Elgasim et al., (1995) explained the protein deposition in animal tissue by the hormonal effect of date pits as a repartitioning agent (acts in a similar way as estrogen) which alters the energy deposition towards protein and away from fat.

Conversely, the high fiber content of the dried fresh date fruits may have affected the availability of nutrients to fish in the higher levels (75 and 100\% DDPW).

\section{Preliminary economic efficiency:}

Data of feed cost required for production one $\mathrm{Kg}$ gain of Nile tilapia, O.niloticus, fed various levels of DDPW are presented in Table (9). Results revealed that as the DDPW level decreased, the cost of feed and the change in feed cost $/ \mathrm{kg}$ gain increased.

The inclusion of DDPW into the diet at 25, 50, 75 and $100 \%$, resulted decreasing feeding costs (LE/ton feed) compared with the control diet. The lowest cost of feed $/ \mathrm{Kg}$ fish gain and the higher change in feed cost $/ \mathrm{Kg}$ gain were $10.00 \mathrm{LE}$ and $30.91 \%$ in the control diet contained $0 \%$ DDPW, respectively.

The change (\%) in feed cost/Kg gain increased with increasing the level of DDPW in the diets. The present results were in harmony with the findings of Srour et al., (2002) with Nile tilapia O.niloticus and catfish, who found that the cost of feed decreased with increasing the level of DDD (dried dropping date) in the diet.

At the low level of replacement (25\% DDD) it was found that tilapia and catfish could be produced cheaper than the control diet by about $4 \%$ less in feeding cost.

Table (9): Cost (LE) of feed required for production of one $\mathrm{Kg}$ gain of Nile tilapia feed the experimental diets

\begin{tabular}{|c|c|c|c|c|c|}
\hline $\begin{array}{c}\text { Diets } \\
\text { no. }\end{array}$ & $\begin{array}{c}\text { Levels of } \\
\text { DDPW }\end{array}$ & $\begin{array}{c}\text { Feed cost } \\
\text { (LE/ton } \\
\text { feed) }\end{array}$ & $\begin{array}{c}\text { Amount of } \\
\text { feed/one Kg } \\
\text { gain(Kg) }\end{array}$ & $\begin{array}{c}\text { Cost of } \\
\text { one Kg } \\
\text { fish gain } \\
\text { (LE) }\end{array}$ & $\begin{array}{c}\% \text { Change } \\
\text { in feed } \\
\text { cost/Kg } \\
\text { gain }\end{array}$ \\
\hline 1 & 0 & 4505.90 & 2.22 & 10.00 & - \\
\hline 2 & 25 & 4416.80 & 2.47 & 12.10 & 121 \\
\hline 3 & 50 & 4320.00 & 4.96 & 21.43 & 214.3 \\
\hline 4 & 75 & 4233.60 & 5.21 & 22.06 & 220.6 \\
\hline 5 & 100 & 4149.50 & 7.45 & 30.91 & 309.1 \\
\hline
\end{tabular}

Feed cost $/ \mathrm{Kg}$ gain $(\mathrm{LE})=$ Feed intake $\times$ cost $(\mathrm{LE})$ of one ton feed $/ 1000 \times$ Total gain .

The cost of ingredients in September 2014: Soybean meal $4100 \mathrm{LE} /$ ton, fish meal $13500 \mathrm{LE} /$ ton, yellow corn $2080 \mathrm{LE} / \mathrm{ton}$, discarded date palm $1000 \mathrm{LE} /$ ton, Rice bran $1750 \mathrm{LE} /$ ton, Wheat bran $1800 \mathrm{LE} / \mathrm{ton}$, vitamin and mineral mixture $23 \mathrm{LE} / 100 \mathrm{~g}$. 
Higher levels of DDD replacement (50, 75 and 100\%) greatly increased the cost of feed required for production of one $\mathrm{Kg}$ fish gain.

Also Nour et al., (2004) with blue tilapia (O.niloticus), found that as the IDDD (inedible dried dropping dates) levels increased, the cost of feeds to produce one $\mathrm{Kg}$ gain of fish decreased and the change in feed cost/kg gain increased. The change (\%) in feed cost/Kg gain increased with increasing the level of DDPW in the diets.

The diets contained 25, 50, 75 and $100 \%$ IDDD, showed in decreasing feeding costs (LE/ton feed) at 4, 9, 13 and $18 \%$, respectively compared with the control diet ( $100 \%$ yellow corn).

\section{CONCLUSIONS}

The results obtained from the present study showed that the control diet (100\% yellow corn) Followed by diet contain $25 \%$ DDPW was the superior in all growth parameters compared with the supplemented discarded date palm at three levels $(, 50,75,100)$.

\section{REFERENCES}

Abd El-Maksoud, A. M. S.; Aboul-Fotoh, G. E.; Allam, S. M.; Abou Zied, R. M. (1999). Effect of Marjoram leaves (Majorana hortensis L.) as a feed additive on the performance of Nile tilapia Oreochromis niloticus fingerlings. Egypt. J. Nutr. And feeds, 2: 39-47.

Aldosari, M.N.; Al-Hozab, A.A.; Hmeidan, M. and Alothaymeen, I. (1995). Discarded dates and wheat straw as ingredients in the rations of growing sheep. Arab Gulf Journal of Scientific Research, Riyadh, Saudi Arabia. 13(1): 123-131.

Al-Hiti, M.K. and Rous, J. (1978). Date waste without stones in broiler diets. British Poultry Science. 19: 17-19.

Alhomidy, S.N., Basmaeil, S.A.N., Al- Owaimer, A.M., El-Wazirand, M. (2011).Effect of Feeding Different Amounts of Discarded Dates on Growth and Efficiency of Digestion in Sheep. Australian Journal of Basic and Applied Sciences, 5(3): 636-640.

Al-Jasser, M.S. (1996) Replacing dietary starchwith pitted date truit in Nile tilapia Oreochromis ni/oticus (L.) feed.Aquaculture Research, 28: 385-389.

Ali, K.T.; Fine, N.C.; Faraj, M. and Sarsam, N.H. (1956). The use of date products in the ration of the lactating dairy cow and the water buffalo. Indian Journal of Veterinary Science. 26: 193-201.

Al-Yousef, Y., Belyea, R.L. and Vandepopuliere, J.M. (1986). Sodium hydroxide treatment of date pits. Pages 103-104 in Proceedings of Second Symposium on date palms. King Faisal University, AlHasa, Saudi Arabia.

A.O.A.C (1990). Official methods of analysis, $15^{\text {Th }}$ Ed. Association of official analysis of chemists, Washington DCP.114. 
Devshony, S., Eteshola, A., \& Shani, A. (1992). Characterisation and some potential application of date palm (Phoenix dactylifera L.) seeds and seeds oil. JAOCS, 69, 595-597.

Duncan, M. B.(1955). Multiple range and multiple F-test. Biometrics, 11:1-42.

Elgasim E.A., Al-Yousef Y.A., Humeida A.M.(1995). Possible hormonal activity of date pits and flesh fed to meat animals. Food Chem., 52, 149-152.

FAO (Food and Agricultural Organization) (2014). Fishery statistics Aquaculture production.

Hussein, A.S; Alhadrami, G.A.and Khalil, Y.H.( 1998). The use of dates and date pits in broiler starter and finisher diets. J. Bio resourceTechnol., 66 (3): 219-223.

Jangaarrd, P. M.; R. G. Ackman and A. J. Spois (1967). Seasonal studies of the fatty acids composition of liver fish. J. Fish Res. Biol. Of Canada, 24; 613-627.

Khalil, A. A. H. (2001). Productive performance of growing lambs fed complete pelleted ration containing different levels of dried sugar beet tops. M.Sc. Thesis,Fac. Of Agric. Tanta Univ., Egypt.

Khalafalla, M. M. E. (2008). Utilization of some medical plants as feed additives for Nile tilapia Oreochromis niloticus feed. Mediterranean Aquaculture Journal 1 (2): 10-19.

Nagib, H.; Al-Yousef, Y.M. and Hmeidan, M. (1994). Partial replacem ent of corn with dates in layer diets. Journal of Applied Animal Resources. 6: 91-96.

Nour, A. A. ,T. M. Srour and Omnia Nour (2004). Utilization of inedible dried dropping dates as a dietary energy source for blue tilapia (Oreochromis Aureus) reared in enclosure nets. The $1^{\text {st }}$ Annual Scientific Conf.Anim. \& fish Prod. August. 73\& 82, Al-Mansoura, Fac. Agric., 2004.

N R C, National research council. (1993). Nutrient requirements of fish. National academy press. Washington.DCP.114.

Omar, E. and Nour, A. A. (1993). Utilization of dropping of immature date fruits in feeding of Nile Tilapia (Oreochromis niloticus). The third symposium on date palm in K.S.A from $17^{\text {th }}$ to $20^{\text {th }}$ jan., 415-423.

Osman G. A. Alhadrami, (1996). Evaluation of dates and date pits as dietary ingredients in Tilapia (Oreochromis Aureus) diets differing in protein sources. Bioresource Technology 57: 81-85.

Osman, M.F.; E. A. Gomaa; M. A. El-Zeiny; A. Abdel baset and Hayam D. saleh (2002). Limitation of including AZOLLA PINNATA in carp (Cyprinus carpinal) diets. Egyption J. Nutr. And feeds. 3 (2): 117-124.

Selmi, H.; Khadi, Z.; Tibaoui, G.; Ben Gapa; Rekik, B. and Rouissi, H. (2011).

Nutritional preliminary characterization of some varieties of date and palm downgraded as ruminant feed Online J. Animal and Feed Res., 1 (2):73-76. 
Shiau, S.Y. and Lin, S.E. (1993). Effect of supplemental dietary chromium and vanadium on the utilization of different carbohydrates intilapia Oreochromis niloticus x O. aureus. Aquaculture. 110: 321-330.

SPSS (1997). Statistical package for the social sciences, Versions 6, SPSS in Ch, Chi-USA.

Srour, T. M.; M. A.Zaki and A. A. Nour (2002). Dried dropping dates (DDD) as a dietary energy source for Nile tilapia (O.niloticus) and African catfish (claias gariepinus).The $1^{\text {st }}$ Annual Scientific Conf.Anim. \& fish Prod. Sept. 24 \& 25, Al-Mansoura, Fac. Agric., 2002.

Tahoun, A. M. A. (2002). Effects of some environmental factors on groth performance and feed utilization of some warm water fishes in earthen ponds and glass aquaria. M. Sc. Thesis, University of Tanta.

Tang Z-X, Shi L-E, Aleid SM (2013). Date fruit: chemical composition, nutritional and medicinal values. J Sci Food Agric 93:2351-2361.

Vandepopuliere, J.M.; Al-Yousef, Y. and Lyons, J.J. (1995). Dates and date pits as ingredients in broiler starting and coturnix quail breeder diets. Poultry Science, 74: 1134-1142.

Yousif, O.M.; Osaman, M.F. and Alhadrami, G. A. (1996). Evaluation of dates and pits as dietary ingredients in tilapia (Oreochromis aureus) diets differing in protein sources. Bioresource$$
\text { الملخص العربي }
$$$$
\text { تأثير مستويات مختلفة من فرز البلح علي أداء النمو لاصباعيات البلطي النيلي }
$$

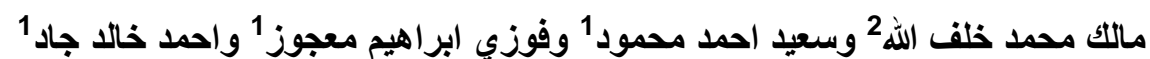

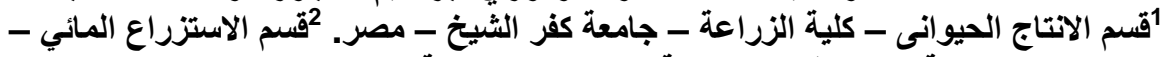

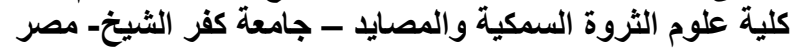$$
\text { أجريت هذه الدر اسه بمعمل بحوث الاسماك, قسم الانتاج الحيواني, كلية الزر اعه, جامعة كفر الثيخ }
$$

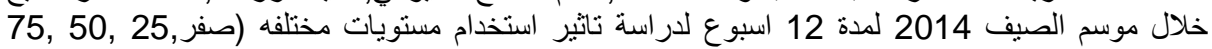$$
\text { , 100\% من البلح المرفوض الكامل مضاف اليه 20\% نخالة القمح علي صفات النمو, و الاستفاده من الغذاء }
$$

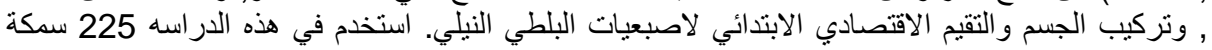

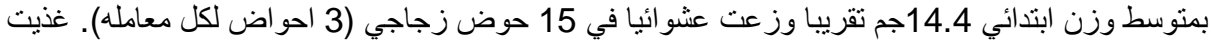

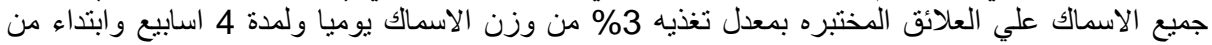

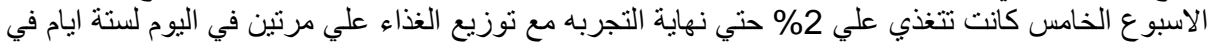

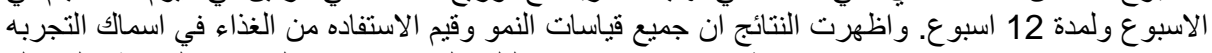

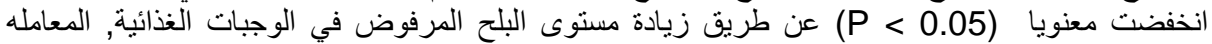

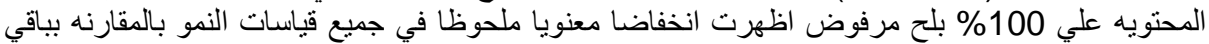

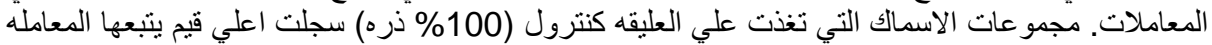$$
\text { الثانيه المحتويه علي 25\% بلح مرفوض بينما مجموعات الاسماك التي تغذت علي العليقه المحتويه علي }
$$$$
\text { 100 \% بلح مرفوض سجلت اقله قيم. }
$$

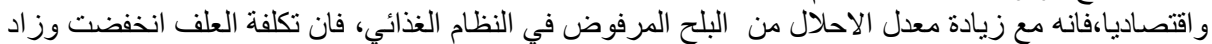

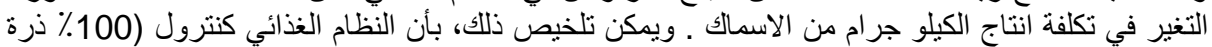

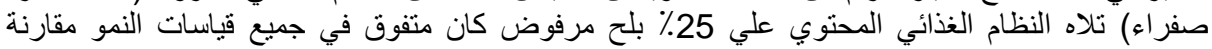

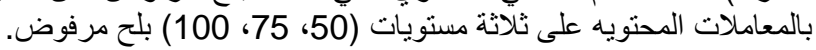

